\title{
Effect of Water Deficit on the Some Qualitative Characteristic of Corn (Zea Maize L.)
}

\author{
Mustafa R. Al-Shaheen ${ }^{{ }^{*}}$, Rabah S. Shareef ${ }^{2}$, Awang Soh Mamat ${ }^{3}$ \\ ${ }^{1}$ College of Agriculture, University of Anbar, Iraq. \\ ${ }^{2}$ College of Applied Sciences - Hit, University of Anbar, Iraq. \\ ${ }^{3}$ School of Bioprocess Engineering, University Malaysia Perlis, Perlis, Malaysia.
}

*Corresponding Author: DeressaKebebe, Oromia Agricultural Research Institute, Holeta Bee Research Center, Oromia, Ethiopia

\begin{abstract}
The present study was carried out at the Agro technology Research Station, University Malaysia Perlis Padang Besar, Perlis, Malaysia from 15/2/2014 the first season, as for the second season have been planted on 15/2/2015. In each year, two experiments were conducted. The objectives of the study were to investigation the effect of water deficit on the corn.

The results showed clearly and significantly decline in the most of the characteristics of study and yield. The results showed a high percentage of Ribonuclease Enzyme and a-amylase enzyme with increased of water deficiency. In the same direction the accumulation of proline has increased remarkably consistent with increased the water deficit.
\end{abstract}

Keywords: Deficit, qualitative, Corn, maize, water.

\section{INTRODUCTION}

The most limiting and most variable environmental factor affecting the productivity of plants is water. Whenever adequate water is not available, farmers have always tried to irrigate their crops. Irrigation water has always been in short supply, but it is becoming a scarce commodity in many regions. Even where it is available, pumping and/or transportation costs have increased dramatically in many locations. Today the profitability of irrigated agriculture is dependent on the efficient use of water [1]. The effective and efficient use of irrigation is dependent on four factors.

- The effect of irrigation on plant production.

- The best system for a given field and water supply.

- Determining how much water to apply at peak usage rate and when to apply it.

- The quality of the water.

Agricultural plants need warm temperatures, sunlight, nutrients, and water to grow. In many regions of the world the required temperature and sunlight are available, but water is not. All plants have a minimum annual water requirement to survive and an optimum annual water requirement for maximum production. Historically, the availability of water has determined where crops can be grown[2]. A high demand crop, such as rice, could not be grown in a region that has a low annual rainfall. In addition, whenever the water available to the plant is less than the optimum amount the production is reduced [3].

Grain maize originated in the tropics, where environmental factors such as high light intensities, high temperatures, and water deficit es exist. Since grain maize possesses the $\mathrm{C} 4$ photosynthetic pathway, it is well adapted to these environmental conditions. The lowest level of photorespiration and high water-use efficiency are responsible for the adaptation of corn to tropical environments [4]. Water deficit or drought probably limits plant production more than any other environmental parameter. Drought is a deficiency of available soil moisture which produces internal water deficits which are severe enough to reduce plant growth. Drought resistance may be attributed to either drought 
tolerance or avoidance. Drought avoidance includes any mechanism which allows the plant to keep its tissue water potential above that which would cause injury to the cells [5]. Roots are very important in plant growth as they absorb soil moisture and nutrients. Drought deficit affects root weight of the plant during water deficit conditions. Root length is often directly related to absorbed water from soil [6]. Root growth is an important drought tolerance mechanism in beans for drought avoidance and absorbing water from a depth of soil, but root growth decreases in drying soil [7]. Proline content accumulation is a common metabolic response of higher plants to water deficits and salinity deficit and substantially increase in both young and old leaves during a dry period.

\section{MATERIALS AND METHODS}

\subsection{Preparation of Field for Planting}

The field plowed and divided to prepare for planting. The plot units measure $2 \mathrm{~m} \times 2 \mathrm{~m}$ each and space, $1 \mathrm{~m}$ apart between the plots unit and between replicate spaced $1.5 \mathrm{~m}$ for the purpose of controlling the water movement. Recommend quantities of NPK fertilizer added to the soil before planting [8]. Soil samples will be collected from the field before planting in different areas at a depth of 20,30, and 40 $\mathrm{cm}$. The samples then are analyzed using standard methods to determine their physical and chemical properties. The corn seeds (seedling length of $5 \mathrm{~cm}$ ) planted in containers using media culture (Peatmoss) for a week and then planting in the field. The seedlings will be planting in rows (spaced 50 $\mathrm{cm}$ apart) and between plants (spaced $25 \mathrm{~cm}$ apart). It has manual weeding continuously during the growing season to ensure the flow of water and distributed evenly on the board.

Were planted on 15/2/2014 the first season, as for the second season have been planted on 15/2/2015. It was estimated the field capacity of the field soil and it was measured the soil moisture directly in the field.

According to the field capacity, which has been measured previously after that soil samples were taken from the experimental treatments at depths $(20,30,40)$ by Soil Auger. Mixed the samples, weighed and put in an electric oven at a temperature of $105 \mathrm{C} 0$ for 24 hours, after drying the samples were weighed and calculated the moisture loss and compared with field capacity, after that, be completed moisture in the soil to field capacity depending on the experimental factors $(25 \%, 50 \%$, and $75 \%$ ).

Statistical analyzed the data In accordance with the design randomized complete block sectors (R.C.B.D) By Program (GenStat Discovery Edition 3) Also been used Least significant difference test L.S.D To distinguish the different statistical averages At the level of probability of 5\% (Steel and Torrie, 1960). The experiment included three treatment for irrigation is given symbols W1, W2, W3. Treatments were distributed indiscriminately in an experiment with three replications.

The methods used as follows:

- Soil texture: estimated by the pipette method as set out in [9] explained in [10].

- Bulk density: estimated in a core sampler method [9] explained in [11].

The soil sample was taken by a vicious cylinder (moist soil) from three different places of experiment field. The soil was chosen randomly. The diameter and height of the cylinder, was measured the sample and then weighed the samples in a sensitive balance and values of these weights was recorded, and then the samples was placed in an oven with temperature of $105^{\circ} \mathrm{c}$ for 8 hours.

Bulk Density $(\mathrm{BD})=[\mathrm{M} \div \mathrm{D}] \times \mathrm{L}$

$\mathrm{BD}=$ bulk density of the soil $(\mathrm{g} / \mathrm{cm} 3)$.

$\mathrm{M}=$ dry sample weight (grams).

$\mathrm{D}=$ cylinder diameter $(\mathrm{cm})$.

$\mathrm{L}=$ Length of the cylinder $(\mathrm{cm})$.

- Electrical conductivity EC: measured in the extract of saturated dough by using a conductivity bridge by way of [12] explained in [13].

- Soil moisture: estimated the percentage of the soil moisture at tensile $33 \mathrm{kpa}$ (field capacity) and $1500 \mathrm{kpa}$ (The wilting point) by using a pressure membrane apparatuspressure plate by the method reported by [9] explain in [14]. 
The percentage of soil moisture is measured on a dry weight basis to calculate the percentage of soil moisture taken a sample of moist soil from 3 different places, at least on the experiment field these places are selected randomly, weighed samples in a sensitive balance and recorded the values of these weights samples be placed in an oven with temperature of $105^{\circ} \mathrm{C}$ for 8 hours, and use the following formula to calculate the moisture content of the soil:

$\mathrm{MC}=\mathrm{W} 1-\mathrm{W} 2$

$\mathrm{MC}=$ moisture content of the soil depending on the dry weight $(\%)$.

$\mathrm{W} 1=$ weight of moist sample (grams).

$\mathrm{W} 2$ = weight of dry sample (grams).

- Determination of soil reaction $(\mathrm{pH})$ : the measurement in leaky saturated soil dough by using $\mathrm{pH}-$ meter according to method cited by [12] , [15].

- Determine of matter: The organic matter was determined by weighing one gram of air-dried soil sample in an Erlenmeyer flask of $500 \mathrm{ml}$ capacity. $10 \mathrm{ml}$ of $1 \mathrm{~N}$ potassium dichromate solution was added at the rate of $10 \mathrm{ml}$ per sample and $20 \mathrm{ml}$ of sulfuric acid (concentrated) was added by means of a pipette. The sample was mixed by shaking and left for 30 minutes. Distilled water at the rate of $150 \mathrm{ml}$ and $0.5 \mathrm{~N}$ ferrous sulfate solutions at the rate of $25 \mathrm{ml}$ was added to the sample and the excess was titrated using $0.1 \mathrm{~N}$ solution of potassium permanganate to pink end point (Moodie et al., 1959).

- Available nitrogen in the soil: ready nitrogen in the soil is estimated by using a micro-Kjeldahl device according to the method of [12].

- Phosphorus determine: estimated according to the method (Olson) as stated [12].

- Potassium: extraction by using an ammonium acetate solution (1n) was estimated by optical flame device flame photometer as stated in [9]. All results were recorded in Table 3.1.

Table1. The chemical and physical properties of the soil before planting.

\begin{tabular}{|c|c|}
\hline Measurement & Value \\
\hline Electrical conductivityds.m $^{-1}$ & 4.89 \\
\hline The degree of soil interaction & 7.35 \\
\hline Nutrients: & 1.12 \\
\hline Total nitrogen (N) \% & 32 \\
\hline Available Phosphors (P) $\left(\mathrm{mg}^{-} \mathrm{kg}^{-1}\right.$ soil) & 96.1 \\
\hline Potassium (K) $\left(\mathrm{mg} . \mathrm{kg}^{-1}\right.$ soil) & 0.18 \\
\hline Organic Metter (OM) $\%$ & 1.22 \\
\hline Apparent density megagram $/ \mathrm{m}^{3}$ & \\
\hline Solumetric distribution of separate soil $) \mathrm{G} . \mathrm{kg}^{1}{ }^{-}$soil( & $70.32 \%$ \\
\hline Sand & $10.74 \%$ \\
\hline Clay & $18.94 \%$ \\
\hline Silt & Sandy Loam \\
\hline Conception & 18.4 \\
\hline Percentage soil moisture when pulling $33 \mathrm{KPa}$ & 6.6 \\
\hline Percentage soil moisture when you lift $1500 \mathrm{kPa}$ & \\
\hline
\end{tabular}

\subsection{Determine the Soil Moisture by the Gravimetric Method (B).}

Soil moisture was measured by following the gravimetric method. It was taken the soil samples at deep $(20,30,40$ and $60 \mathrm{~cm})$, was mixed with samples depending on the experimental factors $(75 \%$, $50 \%, 25 \%$ of field capacity) then weighed moist soil and recorded values, after that all samples was entered to the electric oven at a temperature of 105 for 24 hours after the soil was dry weight again soil moisture calculated according to:

The moisture content of the soil $=\frac{\text { Moist soil weight }- \text { Dry soil weight }}{\text { Dry soil weight }}$

This process was returned every three days for all Experimental treatment. 


\subsection{Irrigation}

According to the field capacity, which has been measured previously after that soil samples were taken from the experimental treatments at depths $(20,30,40,60)$ by Soil Auger. Mixed the samples, weighed and put in an electric oven at a temperature of $105 \mathrm{C} 0$ for 24 hours, after drying the samples were weighed and the moisture loss was calculated and compared with field capacity, after that, be completed moisture in the soil to field capacity depending on the experimental factors $(25 \%, 50 \%$, and $75 \%)$.

\section{Leaf Relative Water CONTENTS (RWC).}

Figure (1) explains the significant influence of water deficit on the Leaf relative water contents (RWC).

Results are shown a superiority of the plants was irrigated (25\% of field capacity) in the highest average of total Leaf relative water contents (RWC), reached (67.67\%), with a significant difference from the other treatment $(50 \%)$ and $(75 \%)$ that has given $(61.32 \%)$ and $(54.33 \%)$ respectively. While the lowest average of total Leaf relative water contents (RWC) in plants was irrigated by $(75 \%$ of field capacity) reached $(54.33 \%)$ with a significant difference from the other treatment (50\% and $25 \%$ of field capacity). This due maybe to resistances to water movement in the plant and the soil is finite, the plants did not absorb water fast enough to replace that lost by transpiration, even though the water potential was relatively high. Because of lack soil moisture and the difficulty of compensated the missing moisture from the plant.

Current results revealed that total Leaf relative water contents are dramatically decreased with the increasing water deficit. These results are in agreement with [16] those of who find a similar decrease of total Leaf relative water contents in alfalfa as a result of drought deficit. The changes in plant water potential might be attributed to a change in osmotic potential.Same way [17] Who confirmed that exposure the plant to water deficit lead to a clear reduction in the water content of the leaves this decrease reflected a negative on the building of carbon and convert nutrients from the source to the sink.

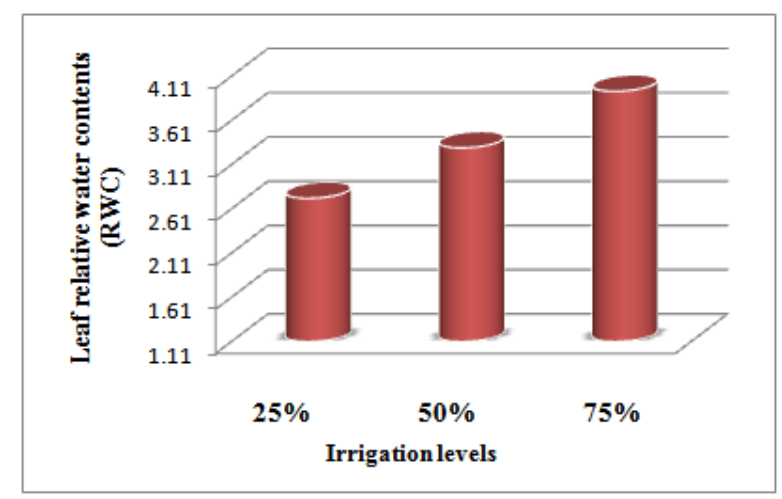

Figure1. Effect of the irrigation levels on the relative water content\% (RWC).

\section{LEVELS OF RibONUCLEASE ENZYME (RNASES) (MMMG-1TISSUE).}

Have emerged from the search results described in the Figure (2) a significant influence of water deficit on thelevels of Ribonuclease enzyme.

Results are shown in the superiority of the plants was irrigated (75\% of field capacity) in the highest average of Ribonuclease enzyme levels, reached $(3.76 \mu \mathrm{m} \mathrm{mg}-1$ tissue), with a significant difference from the other treatment $(50 \%)$ and $(25 \%)$ that has given $(3.23 \mu \mathrm{m} \mathrm{mg}-1$ tissue) and $(2.86 \mu \mathrm{m} \mathrm{mg}-1$ tissue) respectively. While the lowest average of Ribonuclease enzyme levels in plants was irrigated by ( $25 \%$ of field capacity) reached $(2.86 \mu \mathrm{m} \mathrm{mg}-1$ tissue) with a significant difference from the other treatment (50\% and $75 \%$ of field capacity).

Plant tissue is exposed to many changes, including enzymatic changes and changes in the content of carbohydrates and proteins when exposed to water deficit, as studies have shown that moderate water deficit or severe causes an increase in the activity of antioxidant enzymes.

These findings are consistent with [18] who got an increase in the level of Ribonuclease enzyme when exposed the wheat to water deficit. 


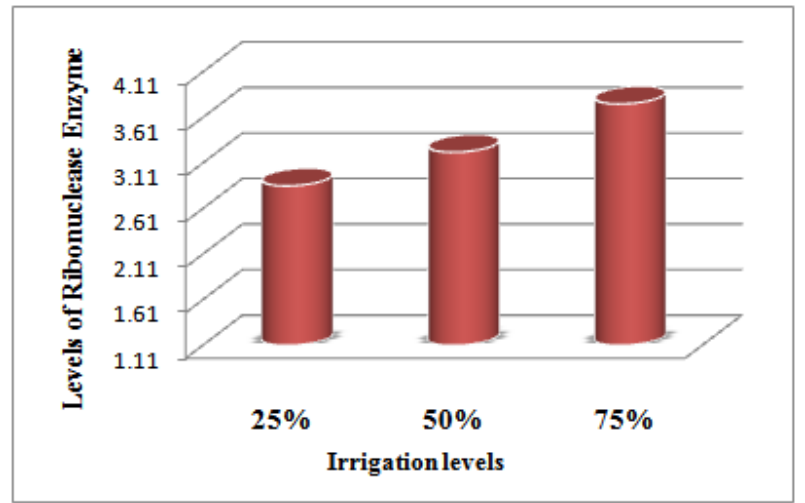

Figure2. Effect of the irrigation levels on the levels of ribonuclease enzyme ( $\mu \mathrm{mg}^{-1}$ tissue).

\section{ESTimAte The LeVels OF AMYlaSe EnZYMe (MM Mg-1 TiSSUe):}

Figure (3) explains the significant influence of water deficit on the levels of amylase enzyme. Amylase shows increased activity in the experimental plants as compared with control treatments. Results are shown a superiority of the plants was irrigated (75\% of field capacity) in the highest

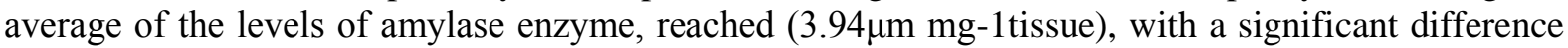
from the other treatment $(50 \%)$ and $(25 \%)$ that has given $(3.30 \mu \mathrm{m} \mathrm{mg-1} \mathrm{tissue)} \mathrm{and}(2.73 \mu \mathrm{m} \mathrm{mg-}$ 1 tissue) respectively. While the lowest average of the levels of amylase enzyme in plants was irrigated by ( $25 \%$ of field capacity) with a significant difference from the other treatment $(75 \%$ and $50 \%$ of field capacity).

Acclimation of plants to drought deficit is considered to promote antioxidant activity. Antioxidant enzymes like catalase, peroxidase and amylase are related to water deficiency and are considered as the main component of antioxidant machinery for drought resistance in plants. This indicated a cumulative increase in total amylase activity in shoots of deficit ed seedlings of tolerant cultivar, resulting in the rapid hydrolysis of transitory starch of shoots, leading to more availability of glucose for shoot growth [19]. Consequently, water deficit tolerance was enhanced by faster hydrolysis of starch in shoot and root due to stimulation of amylase activity, so as to maintain the concentration of low molecular weight carbohydrates, which helped plants to retain turgidity and protect protoplasmic constituents [20]. A drought-induced decrease in starch contents was correlated with inhibition of starch synthase activity. It has been suggested that under water deficit, the products from starch hydrolysis could be used as a substrate for sucrose biosynthesis [21].

These results are consistent with other studies reporting the increased amylase activity in response to drought deficit in.

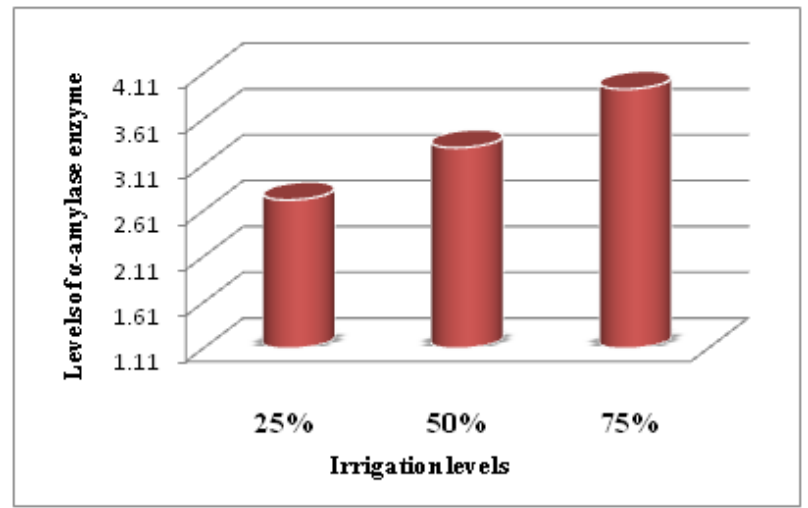

Figure3. Effect of the irrigation levels on the levels ofthe $\alpha$-amylase enzyme ( $\mu \mathrm{mg}^{-1}$ tissue).

\section{CONCLUSION}

The previous results showed the importance of water at all stages of plant growth; also the results showed that the flowering stage is the most important stage of the plant. Irrigate the plant with the quantity it needs is one of the most important ways to rationalize the water use. Using the correct and modern techniques in irrigation will be able to provide irrigation water thereby increasing cultivated areas. 


\section{REFERENCES}

[1] Al-Shaheen, M.R. and A. Soh, Effect of proline and Gibberellic Acid on the qualities and qualitative of Corn (Zea maize L.) under the influence of different levels of the water stress. Int J Sci Res, 2016. 6(5): p. 752-756.

[2] Al-Shaheen, M.R., A. Soh, and G.F. Al-Samarai, Growth responseof corn (Zea Maize L.) To proline and gibberellic acid spray under different irrigation levels. International Journal of Botany and Research (IJBR), 2014. 4(6): p. 7-16.

[3] Al-Shaheen, M.R., et al., Alleviation of water deficit conditions on the corn (zea mays L.) By using gibberellic acid and proline. World J Pharm Pharm Sci, 2016. 5: p. 483-490.

[4] Hallauer, A. and M. Carena, Adaptation of tropical maize germplasm to temperate environments. Euphytica, 2014. 196(1): p. 1-11.

[5] Chang, J., et al., Water stress impacts on transgenic drought-tolerant corn in the northern Great Plains. Agronomy Journal, 2014. 106(1): p. 125-130.

[6] Katerji, N., P. Campi, and M. Mastrorilli, Productivity, evapotranspiration, and water use efficiency of corn and tomato crops simulated by AquaCrop under contrasting water stress conditions in the Mediterranean region. Agricultural water management, 2013. 130: p. 14-26.

[7] Benjamin, J., et al., Water deficit stress effects on corn (Zea mays, L.) root: shoot ratio. Open Journal of Soil Science, 2014. 2014.

[8] Petrus, A.C., et al., Effect of KN-humates on dry matter production and nutrient use efficiency of maize in Sarawak, Malaysia. The Scientific World Journal, 2010. 10: p. 1282-1292.

[9] Black, C.A., D. Evans, and R.C. Dinauer, Methods of soil analysis. Vol. 9. 1965: American Society of Agronomy Madison, WI.

[10] Moritsuka, N., et al., Simple method for measuring soil sand content by nylon mesh sieving. Soil Science and Plant Nutrition, 2015. 61(3): p. 501-505.

[11] Throop, H., et al., When bulk density methods matter: Implications for estimating soil organic carbon pools in rocky soils. Journal of Arid Environments, 2012. 77: p. 66-71.

[12] Page, A.L., Methods of soil analysis. Part 2. Chemical and microbiological properties. 1982: American Society of Agronomy, Soil Science Society of America.

[13] Peralta, N.R. and J.L. Costa, Delineation of management zones with soil apparent electrical conductivity to improve nutrient management. Computers and electronics in agriculture, 2013. 99: p. 218-226.

[14] Cong, Z.-t., H.-f. Lü, and G.-h. Ni, A simplified dynamic method for field capacity estimation and its parameter analysis. Water Science and Engineering, 2014. 7(4): p. 351-362.

[15] Essington, M.E., Soil and water chemistry: An integrative approach. 2015: CRC press.

[16] Slama, I., et al., Differential response to water deficit stress in alfalfa (Medicago sativa) cultivars: Growth, water relations, osmolyte accumulation and lipid peroxidation. African Journal of Biotechnology, 2013. 10(72): p. 16250-16259.

[17] Canavar, O., et al., Determination of the relationship between water use efficiency, carbon isotope discrimination and proline in sunflower genotypes under drought stress. 2014.

[18] Naylor, A.W., Water deficits and nitrogen metabolism. Water deficits and plant growth, 2012. 3: p. 241254.

[19] Ameko, E., et al., A procedure to determine the germination period for optimum amylase activity in maize malt crude extracts for the artisanal production of maltose syrup from fresh cassava starch. Innovative Romanian Food Biotechnology, 2013. 12: p. 52.

[20] Lee, B.R., et al., Water-deficit accumulates sugars by starch degradation — not by de novo synthesis - in white clover leaves (Trifolium repens). Physiologia plantarum, 2008. 134(3): p. 403-411.

[21] Kaur, K., A.K. Gupta, and N. Kaur, Effect of water deficit on carbohydrate status and enzymes of carbohydrate metabolism in seedlings of wheat cultivars. Indian Journal of Biochemistry and Biophysics, 2007. 44(4): p. 223

Citation: Mustafa R. Al-Shaheen, et.al. "Effect of Water Deficit on the Some Qualitative Characteristic of Corn (Zea Maize L.)”. International Journal of Research Studies in Biosciences (IJRSB). 7(11), pp. 20-25. DOI: http://dx.doi.org/10.20431/2349-4050.0711004

Copyright: (C) 2019 Authors this is an open-access article distributed under the terms of the Creative Commons Attribution License, which permits unrestricted use, distribution, and reproduction in any medium, provided the original author and source are credited. 